\title{
Effect of oral booster vaccination of rainbow trout against Yersinia ruckeri depends on type of primary immunization
}

Jaafar, Rzgar M.; Al-Jubury, Azmi; Dalsgaard, Inger; MohammadKarami, Asma; Kania, Per W.; Buchmann, Kurt

\section{Published in:}

Fish and Shellfish Immunology

Link to article, DOI:

10.1016/j.fsi.2017.10.049

Publication date:

2019

Document Version

Peer reviewed version

Link back to DTU Orbit

Citation (APA):

Jaafar, R. M., Al-Jubury, A., Dalsgaard, I., MohammadKarami, A., Kania, P. W., \& Buchmann, K. (2019). Effect of oral booster vaccination of rainbow trout against Yersinia ruckeri depends on type of primary immunization. Fish and Shellfish Immunology, 85, 61-65. https://doi.org/10.1016/j.fsi.2017.10.049

\section{General rights}

Copyright and moral rights for the publications made accessible in the public portal are retained by the authors and/or other copyright owners and it is a condition of accessing publications that users recognise and abide by the legal requirements associated with these rights.

- Users may download and print one copy of any publication from the public portal for the purpose of private study or research.

- You may not further distribute the material or use it for any profit-making activity or commercial gain

- You may freely distribute the URL identifying the publication in the public portal 


\title{
Effect of oral booster vaccination of rainbow trout against Yersinia ruckeri depends on type of primary immunization
}

Rzgar M. Jaafar ${ }^{\mathrm{a}^{*}}$, Azmi Al-Jubury ${ }^{\mathrm{a}}$, Inger Dalsgaard ${ }^{\mathrm{b}}$, Asma MohammadKarami ${ }^{\text {a }}$, Per W. Kania ${ }^{\text {a }}$, Kurt Buchmann ${ }^{\text {a }}$

a Department of Veterinary and Animal Science, Faculty of Health and Medical Sciences, University of Copenhagen, Frederiksberg C, Denmark

b National Veterinary Institute, Technical University of Denmark, Frederiksberg C, Denmark

\begin{abstract}
Vaccination of rainbow trout against Enteric Redmouth Disease (ERM) caused by Yersinia ruckeri can be successfully performed by administering vaccine (a bacterin consisting of formalin killed bacteria) by immersion, bath or injection. Booster immunization is known to increase the protection of fish already primed by one of these vaccination methods. Oral vaccination of trout (administering vaccine in feed) is an even more convenient way of presenting antigen to the fish but the effect of an oral booster has not previously been described in detail. The present work describes to what extent protection may be enhanced by oral boostering following priming with different administration methods. The study confirms that vaccination by $30 \mathrm{sec}$ dip into a bacterin (diluted 1:10) may confer a significant protection compared to non-vaccinated fish. The immunity may be optimized by booster immunization either provided as dip (most effective), bath (less effective) or orally (least effective). Oral immunization may be used as booster after dip but applied as a single oral application it induced merely a slight and statistically non-significant response. It is noteworthy that primary oral immunization followed by an oral booster vaccination showed a trend for an even weaker response. It should be investigated if continued exposure to a low antigen concentration - as performed by two oral immunizations - may induce tolerance to the pathogen and thereby leave the fish more vulnerable.
\end{abstract}


Key words: Vaccination, oral, dip, bath, Yersinia ruckeri, IgM

* Corresponding author.

E-mail address: rezgarhadad@ sund.ku.dk 


\section{Introduction}

Enteric Redmouth Disease ERM is caused by the enterobacterium Yersinia ruckeri and is considered one of the most problematic diseases leading to severe economical losses in freshwater farming of salmon and trout [1]. Clinical signs are bleedings in the mouth, surface tissues (particularly fins and fin bases) and at necropsy hemorrhages are also detected in internal organs including the gastro-intestinal tract $[2,3]$. The disease can be treated by use of various antibiotics but already decades ago vaccination methodologies were tested with some success in traditional trout farms [4-6]. These classical immunoprophylactic studies were performed with the use of formalin killed Y. ruckeri bacteria (bacterin) and administration method studies showed that the way of presenting $Y$. ruckeri antigens to rainbow trout has an important effect on the protective response. Intraperitoneal vaccine injection led to a superior effect compared to dip of trout into the bacterin $[5,7]$. However, protection conferred by dip vaccination may be further improved by booster vaccination either by re-dipping for $30 \mathrm{sec}$ or by bathing fish in a diluted bacterin for at least one hour $[8,9]$. Still injection and dip vaccination procedures are time consuming and if the antigens could be supplied with the fish feed it would reduce handling of fish and labor during vaccination procedures. Oral presentation of $Y$. ruckeri antigens to trout has been tested previously [10, 11] but the protection conferred was generally low. However, oral booster vaccination has been suggested as a way to increase protection, and a commercial vaccine (AquaVac ERM oral, MSD Animal Health) is available, but at present no precise evaluation of this administration method compared to dip or bath is available. We have therefore performed a comparative study in order to determine the relative protective effect of booster vaccination using dip, bath and oral antigen administration. Antibody reactions in the fish were followed by measuring IgM in sera from fish after vaccination and after challenge with live Y. ruckeri bacteria. 


\section{Materials and Methods}

\section{Fish}

A total of 3000 rainbow trout were produced by hatching disinfected trout eggs $\left(7-8{ }^{\circ} \mathrm{C}\right)$ of the Rakkeby strain (Jutland, Denmark) and subsequent rearing $\left(12-13{ }^{\circ} \mathrm{C}\right)$ at the Salmon Hatchery, Bornholm, Denmark, which is a pathogen-free recirculated facility supplied with municipal freshwater [12]. Fish were kept in 14 tanks $\left(1 \mathrm{~m}^{3}\right.$ tanks each containing $700 \mathrm{~L}$ municipal freshwater) and fed (1\% biomass) with commercial standard pelleted feed (Biomar A/S, Brande, Denmark).

\section{Experimental groups and vaccination}

A more comprehensive outline of the schematic overview of the experimental setup can be found in the supplementary materials (Fig. S1). Primary vaccination was performed using 6 months old fish (2160 degree days) with a mean body weight of $3.5 \mathrm{~g}$. The experimental set-up comprised group 1: A total of 1000 rainbow trout kept as unvaccinated control fish, group 2: A total of 1000 rainbow trout immunized by oral vaccination (AquaVac ERM oral, MSD Animal Health) by supplying vaccine $(0.1 \mathrm{ml} /$ fish $)$ in feed ( $1 \%$ biomass per day) over $2 \times 5$ days with a break of 5 days in between according to the manufacturer's recommendations and group 3: A total of 1000 rainbow trout dip vaccinated for $30 \mathrm{~s}$ with AquaVac® RELERA (MSD Animal Health) vaccine (diluted 1:10) containing formalin-inactivated Yersinia ruckeri biotype $1\left(5 \times 10^{9}\right.$ cells/ml) and Y. ruckeri (EX5) biotype $2\left(5 \times 10^{9}\right.$ cells $\left./ \mathrm{ml}\right)$. All fish groups were then kept separately in $1 \mathrm{~m}^{3}$ fish tanks (water volume 700 1). Booster vaccination was conducted 45 days post-primary vaccination and four additional groups were hereby formed and comprisedgroup4: A total of 200 fish orally vaccinated once was orally boostered by giving $0.1 \mathrm{ml}$ vaccine (AquaVac® ERM oral) /fish in feed ( $2 \times 5$ days with a break of 5 days on normal feed in between), group 5: A total of 200 fish dip vaccinated once were boostered by dip into bacterin (AquaVac ${ }^{\circledR}$ RELERA) diluted 1:10 for $30 \mathrm{sec}$, group 6: A total 
of 200 fish vaccinated by dip once was orally booster vaccinated by using AquaVac® ERM oral as described above, and group 7: A total of 200 fish dip vaccinated once were boostered by $1 \mathrm{~h}$ bath (bath vaccination defined as long term exposure to diluted antigen for 1 hour or more) in diluted bacterin (1:1000) (AquaVac® RELERA). Control fish were sham vaccinated by immersion into pure water and by feeding them with commercial standard pelleted feed (Biomar A/S, Brande, Denmark). Thus a total of seven duplicated groups (14 fish tanks) were treated (Table 1).

\section{Fish infection facility}

For the challenge experiment subsamples of fish from all groups were transported to the fish infection facility at the University of Copenhagen, Frederiksberg, Denmark, where they were exposed to live bacteria. At arrival the pathogen free status of fish was confirmed by examining two fish from each group by standard bacteriological and parasitological examination [13]. Fish were acclimatized at $14^{\circ} \mathrm{C}$ for 14 days before experimentation and fed (1\% biomass) with commercial standard pelleted feed (BioMar A/S, Brande, Denmark).

\section{Challenge experiments}

The challenge experiment was performed on day 97 (1358 degree days) post-primary vaccination by exposing (using i.p. injection) 3 subgroups of each treatment to three different dosages of $Y$. ruckeri serotype $\mathrm{O} 1$ biotype 2 (100415-1/4): 1) low dosage (6.5 x $\left.\left.10^{4} \mathrm{cfu} / \mathrm{fish}\right), 2\right)$ medium dosage $\left(6.5 \times 10^{5} \mathrm{cfu} / \mathrm{fish}\right)$ and 3$)$ high dosage $\left(6.5 \times 10^{6} \mathrm{cfu} / \mathrm{fish}\right)$, respectively. The $Y$. ruckeri strain used was isolated from a Danish fish farm [14] and further characterized according to Wheeler et al. [15]. All exposures were performed in duplicate $(2 \times 25$ fish). Experimental fish were anesthetized with MS222 $(50 \mathrm{mg} / \mathrm{l})$ and live bacteria were administered by intraperitoneal injection of $100 \mu \mathrm{l}$ bacterial suspension. After administration of the live bacteria groups of challenged fish were returned to individual fish tanks (water volume 100 1). Fish were observed with $2 \mathrm{~h}$ intervals following challenge and moribund fish were removed, and euthanized in an overdose (300 mg/l) of MS-222 
(Tricaine methane sulphonate, Sigma-Aldrich). Y. ruckeri O1 biotype 2 was re-isolated from head kidney of freshly euthanized fish (2 fish/group) on blood agar plates to confirm that the disease was caused by the challenge strain [14].

\section{Sampling}

Blood sampling was conducted by caudal vein puncture (ten samples per group) at three time points: at 52 days (728 degree days) and 90 days (1260 degree days) post primary vaccination/ 45 days post booster (45 dpb) (before exposure to live bacteria) and at 3 weeks post-challenge (from fish exposed to a low dosage of $Y$. ruckeri) corresponding to 119 days/ 74 dpb (1666 degree days) after the primary vaccination. Blood was kept at $4{ }^{\circ} \mathrm{C}$ overnight, centrifuged at $3000 \mathrm{~g}$ for $10 \mathrm{~min}$ (4 ${ }^{\circ} \mathrm{C}$ ), and serum separated and stored at $-80{ }^{\circ} \mathrm{C}$ until measurement of specific antibody levels against Y. ruckeri.

\section{Antibody analysis}

Specific antibody in fish raised against Y. ruckeri was measured by ELISA according to Chettri et al. [7, 16]. In brief, a 48 h $Y$. ruckeri O1 biotype 2 (100415-1/4) culture (LB culture medium) was used for coating microtiter plates. Plates were washed three times in washing buffer (PBS pH 7.4 with $0.1 \%$ Tween 20 ) and non-specific binding sites were blocked by incubation with $2 \%$ bovine serum albumin (BSA) in PBS for $1 \mathrm{~h}$ at room temperature. Serum samples from all groups were analyzed in duplicate wells. A diluted serum sample (100 $\mu$, diluted 1:50 and 1:100) was added to the plate and incubated $12 \mathrm{~h}$ at $4{ }^{\circ} \mathrm{C}$. After 3 times wash each well was incubated with mouse antisalmonid Ig (dilution 1:500; AbD Serotec Cat. MCA2182, Dusseldorf, Germany) for $1 \mathrm{~h}$ at room temperature on an orbital shaker $(50 \mathrm{rpm})$ which was followed by 3 times washing and incubation with HRP (horseradish peroxidase) conjugated rabbit anti-mouse IgG (dilution 1:500; AbD Serotec Cat. STAR13B, Dusseldorf, Germany) for $1 \mathrm{~h}$ at room temperature as above. Chromogenic substrate TMB (AbD Serotec Cat. No. BUF042B, Dusseldorf, Germany) was then added, the 
reaction stopped after 15 min by adding $1 \mathrm{~N} \mathrm{HCl}$ and $\mathrm{OD}$ read at $450 \mathrm{~mm}$ in an Epoch spectrophotometer (Biotek Instruments, Inc. Winooski, USA).

\section{Statistical analysis}

Normality test (Shapiro-Wilk) was conducted for the evaluation of the normal distribution of data within each group. The software GraphPad Prism 5 was used for creating graphs and performing statistical analysis. Mortality data from the infection experiment were analyzed by the KaplanMeier test and differences among groups were tested using one way ANOVA with Tukey's post hoc test after combining data from the replicates. ELISA data are presented from 1:50 serum dilutions and differences in antibody level (OD) between groups were tested using Student's $t$-test and Mann-Whitney $U$ test. Groups were considered significantly different when $\mathrm{P}<0.05$.

\section{Results}

\section{Survival following challenge}

No significant differences were found between duplicate tanks, which allowed pooling of mortality counts from these for further analysis. In order to detect the vaccine effect, the challenge dosage was adjusted at three different levels which elicited different mortality rates in vaccinated fish. The best survival rate was seen in fish vaccinated twice by dip vaccination $(2 \mathrm{x}$ dip). Fish receiving the low challenge dosage showed a higher survival rate compared to fish challenged with medium and high dosages. Survival rates were $97 \%$ and $92 \%$ in group 5 ( $2 \times \operatorname{dip})$ and 7 ( 1 x dip $+1 \times$ bath), respectively. Fish immunized once by $1 \mathrm{x}$ dip and twice by $1 \mathrm{x}$ dip $+1 \mathrm{x}$ oral showed survival rates of $69 \%$ and $68 \%$, respectively. Non-immunized control fish showed a survival rate of $49 \%$ which was not significantly different from fish exposed to $1 \mathrm{x}$ oral and $2 \mathrm{x}$ oral (44\%) (Table 2) (Fig. 1A). Fish challenged with the medium dose exhibited $83 \%, 56 \%$, and $49 \%$ survival (groups exposed to $2 \times \operatorname{dip}, 1 \times \operatorname{dip}+1 \times$ bath, and $1 \times \operatorname{dip}$ fish), respectively. The other vaccinated fish showed $31 \%$, $28 \%, 11 \%$, and $5 \%$ survival rates $(1 \times \mathrm{dip}+1 \mathrm{x}$ oral, $1 \mathrm{x}$ oral, control, and $2 \mathrm{x}$ oral), respectively 
(Table 2) and (Fig. 1B). Fish injected with the high dose of $Y$. ruckeri exhibited a relatively high mortality even in vaccinated fish. Non-immunized control fish and fish receiving $2 \mathrm{x}$ oral vaccination exhibited comparable survival rate $5 \%$ and $6 \%$, respectively. Fish dip immunized once (1 x dip) and orally immunized once (1 x oral) showed survival rates of 11 and $13 \%$, respectively. Fish vaccinated once by dip and boostered orally $(1 \mathrm{x}$ dip $+1 \mathrm{x}$ oral $)$ or boostered by bath $(1 \mathrm{x} \operatorname{dip}+$ $1 \mathrm{x}$ bath) exhibited survival rates of $22 \%$ and $28 \%$, respectively. Fish dip vaccinated twice $(2 \mathrm{x}$ dip) showed the best resistance with a $40 \%$ survival rate (Table 2) and (Fig. 1C).

Antibody responses measured by ELISA

At 52 days post-vaccination (pre-challenge) no significant differences were found with regard to antibody (IgM) levels between control, one time dip vaccination (1 x dip), and one time oral vaccination (1 x oral) (Fig. 2A). Samples from fish taken 45 days after boostering (but before challenge) showed a slight but significant elevation of antibody levels in all groups which had received booster vaccination ( $2 \mathrm{x}$ oral, $2 \mathrm{x}$ dip, and $1 \mathrm{x}$ dip $+1 \mathrm{x}$ bath), except of fish which had received $1 \mathrm{x} \operatorname{dip}+1 \mathrm{x}$ oral, while control and one time vaccinated fish $(1 \mathrm{x}$ oral and $1 \mathrm{x}$ dip) showed no change of antibody levels (Fig. 2B). Three weeks post-challenge (74 dpb) the antibody levels were elevated in all groups. In general, all groups exhibited higher antibody level compared to the level before challenge. Only two groups $(1 \mathrm{x} \operatorname{dip}+1 \mathrm{x}$ oral $)$ and $(1 \mathrm{x} \operatorname{dip}+1 \mathrm{x}$ bath $)$ exhibited significantly higher antibody responses compared to challenged but previously naïve (nonvaccinated) fish (Fig. 2C). 


\section{Discussion}

It is generally recognized that the administration methods applied when vaccinating fish play a crucial role for the protection induced [5]. Injection vaccination provides a superior protection of rainbow trout towards Yersinia ruckeri compared to dip (short term immersion into a high concentration bacterin) and bath (long term bath in a low concentration bacterin) [16]. If adjuvants are combined with the vaccine antigens the protection after injection vaccination can be even higher [7]. However, small fish with a body weight of a few grams are not easily handled for injection vaccination and alternative administration methods or booster immunization may instead be optimized in order to achieve higher protection [5]. Thus, boostering by dip or bath has been shown to be effective both in the laboratory and in the field $[8,9]$. Oral administration of vaccine may be an additional way to administer booster immunization but the precise effect of this methodology has remained unclear. The present investigation elucidated to which extent ERM vaccine antigens provided in fish feed confer immunity of rainbow trout against $Y$. ruckeri infection. A primary oral vaccination of small rainbow trout - by feeding each fish over $2 \times 5$ days with a total of $0.1 \mathrm{ml}$ vaccine in feed - only interrupted by a 5 day break - gave the fish a slight (statistically insignificant) protection against $Y$. ruckeri infection. However, if used as booster vaccination - after a primary dip vaccination in a bacterin diluted 1:10 for $30 \mathrm{sec}$ - the oral administration provided led to a slightly increased protection when exposed to a medium or a high concentration of live $Y$. ruckeri bacteria. When an effective primary immunization against ERM has taken place it seems that boostering by the oral route may lift the response slightly. However, the study did also show that oral vaccination may not always be beneficial. If oral administration was used twice - without any prior strong immunization - a trend for a slightly (although statistically non-significant) decreased disease resistance (elevated mortality after challenge) was noted. It cannot be excluded that the low protection following two times oral antigen administration may be caused by induction of tolerance 
to the pathogen. Induction of tolerance is a basic mechanism in the immune system $[17,18]$ as responses in a host against some antigens including self-antigens are clearly devastating. Therefore such auto-reactions must be avoided and during the ontogenetic development of the immune system the host organism exerts clonal deletion of self-reactive lymphocyte clones [19]. In addition, host reactions against microbiotas (associated with the skin, gills and gut) must be tightly regulated as exacerbated inflammatory reactions would be highly problematic as there is a constant bacterial exposure of outer or inner mucosal surfaces. Thus, the highly debilitating condition IBD (Inflammatory Bowel Disease), which is widespread in the industrialized part of the world, is caused by a severe inflammatory reaction of the host intestinal immune system against even benign gut microorganisms $[20,21]$. Therefore, the host must be able to activate and apply immunological pathways in order to achieve tolerance to certain microorganisms which are recognized as nonharmful, unable to penetrate the host or occur in that low densities that they are not perceived a danger by the host. These regulatory immune mechanisms may explain the inferior efficacies achieved after dermal vaccination against tuberculosis in certain areas where the human population is continuously exposed to environmental mycobacteria [22]. Correspondingly, mice orally immunized against antigens may exhibit a depressed reaction and immunity development towards these specific antigens [23]. Tolerance may include the action of regulatory T-cells with depression of cytokine expression [24] and possibly other immune mechanisms. It can therefore not be excluded that oral vaccination against ERM using feeding with a low concentration of formalin killed $Y$. ruckeri will initiate a state of immunological memory in rainbow trout but due to the evidently non-pathogenic nature of the killed antigens, combined with the extremely low concentrations, the tolerance pathway may be activated. To what extent the rainbow trout immune system applies Treg cells, immune regulating cytokines or other mechanisms in this process should be further investigated. It is generally found that immersion of fish into a bacterin merely elicits a 
very low antibody reaction [25] and we have previously illustrated that antibody levels in sera were elevated post-vaccination particularly in injection and twice immersion vaccinated fish. In the present study we saw merely a light (but statistically significant) elevation of Ig levels in boostered trout which were best protected groups but this may point to the importance of antibody based protection as corresponding to previous work on the role of humoral immunity of rainbow trout in elimination $Y$. ruckeri $[7,8]$. In addition, we showed in a previous study that the densities of $\operatorname{IgM}$ positive lymphocytes in trout spleens were significantly higher in fish immersed three times in bacterin compared to control fish [26]. In the present study the ELISA data showed that some immunological priming must have taken place as exposure to the live $Y$. ruckeri induced different antibody elevations in the differently primed groups - including fish immunized orally twice. Therefore protection is not solely reflected by antibody levels but must also involve various cellular reactions and regulatory mechanisms. This notion is supported by previous studies indicating that cellular mechanisms contribute to immunity against $Y$. ruckeri. Thus, expression levels of rainbow trout immune genes including T-cell markers (TcR, CD8 $\alpha$ and CD4) were elevated in spleen tissue of rainbow trout dip-vaccinated against $Y$. ruckeri [27]. Further, expression levels of genes encoding $\mathrm{CD}^{+} \mathrm{T}$ (T-helper/TH), $\mathrm{T}_{\mathrm{H}} 1, \mathrm{~T}_{\mathrm{H}} 2, \mathrm{~T}_{\mathrm{H}} 17$, Tregs, and $\mathrm{CD}^{+} \mathrm{T}$ (cytotoxic $\mathrm{T}$ lymphocytes/CTLs) markers were up-regulated in challenged fish groups [7]. This indicates that protection of trout is regulated by an intricate network of immune factors in accordance with previous studies on vaccinated salmonids $[28,29,30]$.

In conclusion the present study confirmed that dip vaccination combined with boostering by dip, bath or oral antigen presentation will elevate the protection against $Y$. ruckeri. However, it is noteworthy that a primary oral immunization followed by a corresponding oral booster left trout as susceptible as naïve control fish. 


\section{Acknowledgment}

This investigation was supported by The Danish Ministry of Food, Agriculture and Fisheries under the GUDP program (Vaxfisk, grant no. 34009-15-0960) and the European commission (FP7 Targetfish contract no. 311993). The authors are indebted to Gert Jørgensen at the Bornholm Salmon Hatchery for assistance with fish keeping during the project. 


\section{References}

[1] E. Tobback, A. Decostere, K. Hermans, F. Haesebrouck, K. Chiers, Yersinia ruckeri infections in salmonid fish, J Fish Dis 30(5) (2007) 257-268.

[2] J.L. Romalde, A.E. Toranzo, Pathological Activities of Yersinia ruckeri, the Enteric Redmouth (Erm) Bacterium, Fems Microbiol Lett 112(3) (1993) 291-300.

[3] S. Deshmukh, P.W. Kania, J.K. Chettri, J. Skov, A.M. Bojesen, I. Dalsgaard, K. Buchmann, Insight from Molecular, Pathological, and Immunohistochemical Studies on Cellular and Humoral Mechanisms Responsible for Vaccine-Induced Protection of Rainbow Trout against Yersinia ruckeri, Clinic Vacc Immunol 20(10) (2013) 1623-1641.

[4] K.A. Johnson, J.K. Flynn, D.F. Amend, Duration of Immunity in Salmonids Vaccinated by Direct Immersion with Yersinia ruckeri and Vibrio anguillarum Bacterins, J Fish Dis 5(3) (1982) 207-213.

[5] K.A. Johnson, D.F. Amend, Comparison of Efficacy of Several Delivery Methods Using Yersinia ruckeri Bacterin on Rainbow trout, Salmo gairdneri Richardson, J Fish Dis 6(4) (1983) 331-336.

[6] S.G. Newman, J.J. Majnarich, Direct Immersion Vaccination of Juvenile Rainbow Trout, Salmo gairdneri Richardson, and Juvenile Coho Salmon, Oncorhynchus kisutch (Walbaum), with a Yersinia ruckeri Bacterin, J Fish Dis 5(4) (1982) 339-341.

[7] R.M. Jaafar, J.K. Chettri, I. Dalsgaard, A. Al-Jubury, P.W. Kania, J. Skov, K. Buchmann, Effects of adjuvant Montanide (TM) ISA 763 A VG in rainbow trout injection vaccinated against Yersinia ruckeri, Fish Shellfish Immun 47(2) (2015) 797-806.

[8] J.K. Chettri, R.M. Jaafar, J. Skov, P.W. Kania, I. Dalsgaard, K. Buchmann, Booster immersion vaccination using diluted Yersinia ruckeri bacterin confers protection against ERM in rainbow trout, Aquaculture 440 (2015) 1-5.

[9] J.G.H. Schmidt, N. H. Buchmann, K., ERM booster vaccination of rainbow trout using diluted bacterin: Field study, Aquaculture 464 (2016) 262-267.

[10] A. Ross., G.W. Klontz., Oral immunization of rainbow trout Salmo gairdneri against an etiological agent of redmouth disease. J Fish Res Board Canada 22 (1965) 713-719.

[11] D.P. Anderson, J.R. Nelson, Comparison of Protection in Rainbow Trout (Salmo gairdneri) Inoculated with and Fed Hagerman Redmouth Bacterins, J Fish Res Board Canada 31(2) (1974) 214-216. 
[12] J. Xueqin, P.W. Kania, K. Buchmann, Comparative effects of four feed types on white spot disease susceptibility and skin immune parameters in rainbow trout, Oncorhynchus mykiss (Walbaum), J Fish Dis 35(2) (2012) 127-135.

[13] K. Buchmann, An introduction to fish parasitological methods- classical and molecular techniques, (2007), Biofolia, Frederiksberg, Denmark.

[14] I. Dalsgaard, L. Madsen, Bacterial pathogens in rainbow trout, Oncorhynchus mykiss (Walbaum), reared at Danish freshwater farms, J Fish Dis 23(3) (2000) 199-209.

[15] R.W. Wheeler, R.L. Davies, I. Dalsgaard, J. Garcia, T.J. Welch, S. Wagley, K.S. Bateman, D.W. Verner-Jeffreys, Yersinia ruckeri biotype 2 isolates from mainland Europe and the UK likely represent different clonal groups, Dis Aquat Organ 84 (2009) 25-33.

[16] J.K. Chettri, S. Deshmukh, L. Holten-Andersen, R.M. Jafaar, I. Dalsgaard, K. Buchmann, Comparative evaluation of administration methods for a vaccine protecting rainbow trout against Yersinia ruckeri $\mathrm{O} 1$ biotype 2 infections, Vet Immunol Immunopathol 154 (1-2) (2013) 42-47.

[17] P.H.M. Joosten, M.Y. Engelsma, M.D. van der Zee, J.H.W.M. Rombout, Induction of oral tolerance in carp (Cyprinus carpio L) after feeding protein antigens, Vet Immunol Immunopathol 60(1-2) (1997) 187-196.

[18] B. Dubois, A. Goubier, G. Joubert, D. Kaiserlian, Oral tolerance and regulation of mucosal immunity, Cell Mol Life Sci 62(12) (2005) 1322-1332.

[19] G.J.V. Nossal, Negative Selection of Lymphocytes, Cell 76(2) (1994) 229-239.

[20] R.J. Xavier, D.K. Podolsky, Unravelling the pathogenesis of inflammatory bowel disease, Nature 448(7152) (2007) 427-434.

[21] C.D. Packey, R.B. Sartor, Commensal bacteria, traditional and opportunistic pathogens, dysbiosis and bacterial killing in inflammatory bowel diseases, Curr Opin Infect Dis 22(3) (2009) 292-301.

[22] D.N. Price, D.F. Kusewitt, C.A. Lino, A.A. McBride, P. Muttil, Oral Tolerance to Environmental Mycobacteria Interferes with Intradermal, but Not Pulmonary, Immunization against Tuberculosis, Plos Pathog 12(5) (2016).

[23] K. Kapp, J. Maul, A. Hostmann, P. Mundt, J.C.Preiss, A. Wenzel, A. Thiel, M. Zeitz, R. Ullrich, R. Duchmann, Modulation of systemic antigen-specific immune responses by oral antigen in humans. Eur J Immunol 40 (11) (2010) 3128-3137 
[24] Y. Chen., V.K. Kuchroo., J.I. Inobe., D.A. Hafler., H.L. Weiner., Regulatory T Cell Clones Induced by Oral Tolerance: Suppression of Autoimmune Encephalomyelitis, Science 265 (1994) 1237-1240.

[25] M. Cossarini-Dunier., Protection against enteric redmouth disease in rainbow trout, Salmo gairdneri Richardson, after vaccination with Yersinia ruckeri bacterin., J Fish Dis 9 (1986) 27-33.

[26] R.M. Jaafar, A. Al-Jubury, J.K. Chettri, I. Dalsgaard, P.W. Kania, K. Buchmann, Secondary immune response of rainbow trout following repeated immersion vaccination, J Fish Dis (2017) 17.

[27] M. K. Raida., K. Buchmann., Bath vaccination of rainbow trout (Oncorhynchus mykiss Walbaum) against Yersinia ruckeri: Effects of temperature on protection and gene expression, Vaccine 26 (2008) 1050-1062.

[28] J.K. Chettri, J. Skov, R.M. Jaafar, B. Krossøy, W.P. Kania, I. Dalsgaard, et al., Comparative evaluation of infection methods and environmental factors on challenge success: Aeromonas salmonicida infection in vaccinated rainbow trout, Fish Shellfish Immunol. 44 (2015) 485-495.

[29] S. Mutoloki, G.A. Cooper, I.S. Marjara, B.F. Koop, O. Evensen, High gene expression of inflammatory markers and IL-17A correlates with severity of injection site reactions of Atlantic salmon vaccinated with oil-adjuvanted vaccines, BMC Genom. 11 (2010) 1-15.

[30] J. Kumari, J. Bøgwald, R.A. Dalmo, Vaccination of Atlantic salmon, Salmo salar L., with Aeromonas salmonicida and infectious pancreatic necrosis virus (IPNV) showed a mixed Th1/Th2/Treg response, J. Fish Dis. 36 (2013) 881-886. 


\section{Tables:}

Table 1. Treatment groups. Seven duplicated groups were formed. Fish were immunized by oral and dip vaccination. Oral vaccination (AquaVac ERM oral) was conducted by administrating vaccine $0.1 \mathrm{ml} /$ fish in feed ( $1 \%$ biomass per day) $2 \times 5$ days with a break of 5 days in between according to the manufacturer's recommendations. Dip vaccination was performed by vaccinating fish for $30 \mathrm{~s}$ with AquaVac® RELERA (MSD Animal Health) vaccine (diluted 1:10) containing formalin-inactivated Yersinia ruckeri biotype $1\left(5 \times 10^{9}\right.$ cells $\left./ \mathrm{ml}\right)$ and EX5 biogroup Y. ruckeri biotype $2\left(5 \times 10^{9}\right.$ cells $\left./ \mathrm{ml}\right)$. Control fish were sham vaccinated by dipping into pure water or feeding them with commercial standard pelleted feed (Biomar A/S, Brande, Denmark).

Tabel 2. Statistics of survival data presented in fig. 1. In order to elucidate differences between the treatment groups one way ANOVA with Tukey's post hoc test was conducted. NS: no significant difference. *: $\mathrm{p}<0.5, * *: \mathrm{p}<0.01, * * *: \mathrm{p}<0.001$.

\section{Figures:}

Figure 1: Percentage survival (Kaplan-Meier) of rainbow trout in different experimental groups following challenge 97 days post- $1^{\text {st }}$ vaccination by three different doses (low, medium, and high) with Yersinia ruckeri $\mathrm{O} 1$ biotype 2. Differences among groups were tested using one way ANOVA with Tukey's post hoc test after combining data from the replicates. A: Low dose $\left(6.5 \times 10^{4}\right.$ cfu/fish). B: Medium dose (6.5 x $10^{5} \mathrm{cfu} /$ fish). C: High dose $\left(6.5 \times 10^{6} \mathrm{cfu} / \mathrm{fish}\right)$.

Figure. 2. Yersinia ruckeri specific antibody (IgM) levels measured by ELISA (enzyme-linked immunosorbent assay). Each symbol represents a single fish (total of 10 fish/group were analyzed) and average antibody level in each group is shown by horizontal line. A: Pre-challenge (52 days post- $1^{\text {st }}$ vaccination). B: Pre-challenge (97 days post- $1^{\text {st }}$ vaccination/ 45 days post-booster). C: Three weeks post- exposure to live bacteria (126 days post- ${ }^{\text {st }}$ vaccination/ 74 days post-booster). Student's $t$-test and Mann-Whitney $U$ test $(*, \mathrm{P}<0.05)$.

Supplementary figure: Schematic overview of the experimental setup. 


\section{Table 1}

\begin{tabular}{cll}
\hline Group no. & \multicolumn{1}{c}{ Treatment } & Group ID \\
\hline 1 & Sham vaccinated control (No vaccination at all) & Control \\
2 & One time oral vaccination (AquaVac ERM oral) & $1 \times$ oral \\
3 & One time dip vaccination (AquaVac® RELERA) & $1 \times$ dip \\
4 & Two times oral vaccination (AquaVac ERM oral) & $2 \times$ oral \\
5 & Two times dip vaccination (AquaVac® RELERA) & $2 \times$ dip \\
6 & One time dip vaccination + One time oral vaccination & $1 \times$ dip $+1 \times$ oral \\
7 & One time dip vaccination + One time bath vaccination & $1 \times$ dip + 1 x bath \\
\hline
\end{tabular}


Table 2:

\begin{tabular}{|c|c|c|c|c|c|c|c|}
\hline & $1 \mathrm{x}$ oral & $1 \mathrm{x}$ dip. & $2 \times$ oral & $2 \mathrm{x}$ dip. & $\begin{array}{l}1 \mathrm{x} \text { dip. } \\
+1 \mathrm{x} \text { oral }\end{array}$ & $\begin{array}{c}1 \times \text { dip. } \\
+1 \times \text { bath }\end{array}$ & $\begin{array}{c}\text { Percentage } \\
\text { survival }\end{array}$ \\
\hline \multicolumn{8}{|c|}{ Low dose $\left(6.5 \times 10^{4}\right.$ cfu/fish $)$} \\
\hline Control & NS & NS & NS & $* * *$ & NS & $* * *$ & 49 \\
\hline $1 \times$ oral & & NS & NS & $* * *$ & NS & $* * *$ & 44 \\
\hline $1 \times \operatorname{dip}$ & & & NS & NS & NS & NS & 69 \\
\hline $2 \times$ oral & & & & $* * *$ & NS & $* * *$ & 44 \\
\hline 2 x dip. & & & & & NS & NS & 97 \\
\hline $1 \times \operatorname{dip}+1 \times$ oral & & & & & & NS & 68 \\
\hline $1 \mathrm{x} \operatorname{dip}+1 \mathrm{x}$ bath & & & & & & & 92 \\
\hline \multicolumn{8}{|c|}{ Medium dose $\left(6.5 \times 10^{5} \mathrm{cfu} / \mathrm{fish}\right)$} \\
\hline Control & NS & $* *$ & NS & $* * *$ & NS & $* * *$ & 11 \\
\hline $1 \times$ oral & & NS & NS & $* * *$ & NS & NS & 28 \\
\hline $1 \times \operatorname{dip}$ & & & $* * *$ & $*$ & NS & NS & 49 \\
\hline $2 \times$ oral & & & & & NS & $* * *$ & 5 \\
\hline $2 \times \operatorname{dip}$ & & & & & $* * *$ & NS & 83 \\
\hline $1 \times \operatorname{dip}+1 \times$ oral & & & & & & NS & 31 \\
\hline $1 \times \operatorname{dip}+1 \times$ bath & & & & 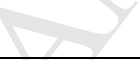 & & & 56 \\
\hline \multicolumn{8}{|c|}{ High dose $\left(6.5 \times 10^{6} \mathrm{cfu} / \mathrm{fish}\right)$} \\
\hline Control & NS & NS & NS & ** & NS & NS & 5 \\
\hline $1 \times$ oral & & NS & NS & $*$ & NS & NS & 13 \\
\hline $1 \times \operatorname{dip}$ & & & NS & $*$ & NS & NS & 11 \\
\hline $2 \times$ oral & & & & $* *$ & NS & NS & 6 \\
\hline $2 \times \operatorname{dip}$ & & & & & NS & NS & 40 \\
\hline $1 \times \operatorname{dip}+1 \times$ oral & & & & & & NS & 22 \\
\hline $1 \times \operatorname{dip}+1 \times$ bath & & & & & & & 28 \\
\hline
\end{tabular}


A) Low dose $\left(6.5 \times 10^{4} \mathrm{cfu} / \mathrm{fish}\right)$

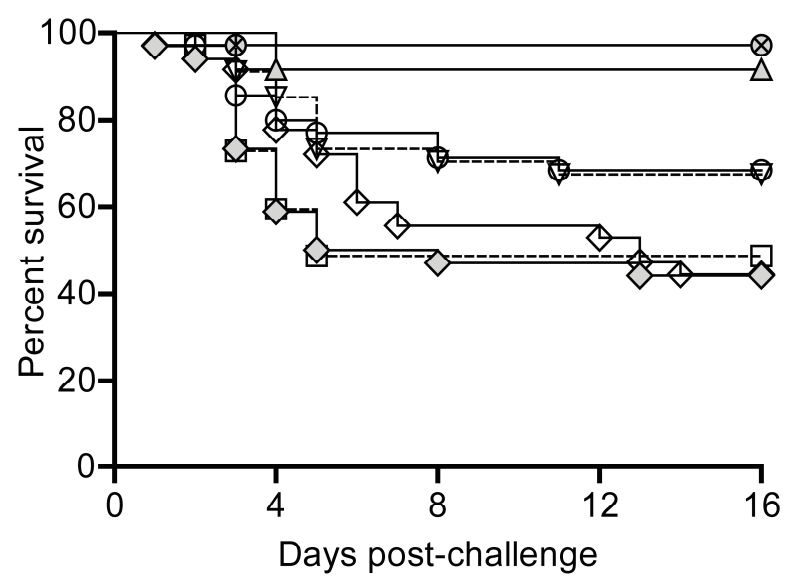

$$
\begin{aligned}
& -\boxminus-\text { Control } \\
& \diamond 1 \times \text { oral } \\
& -1 \times \text { dip } \\
& \diamond-2 \times \text { oral } \\
& -\otimes-2 \times \text { dip } \\
& -\nabla-1 \times \text { dip }+1 \times \text { oral } \\
& -1 \times \text { dip }+1 \times \text { bath }
\end{aligned}
$$

B) Medium dose $\left(6.5 \times 10^{5} \mathrm{cfu} / \mathrm{fish}\right)$

A) High dose $\left(6.5 \times 10^{6} \mathrm{cfu} / \mathrm{fish}\right)$
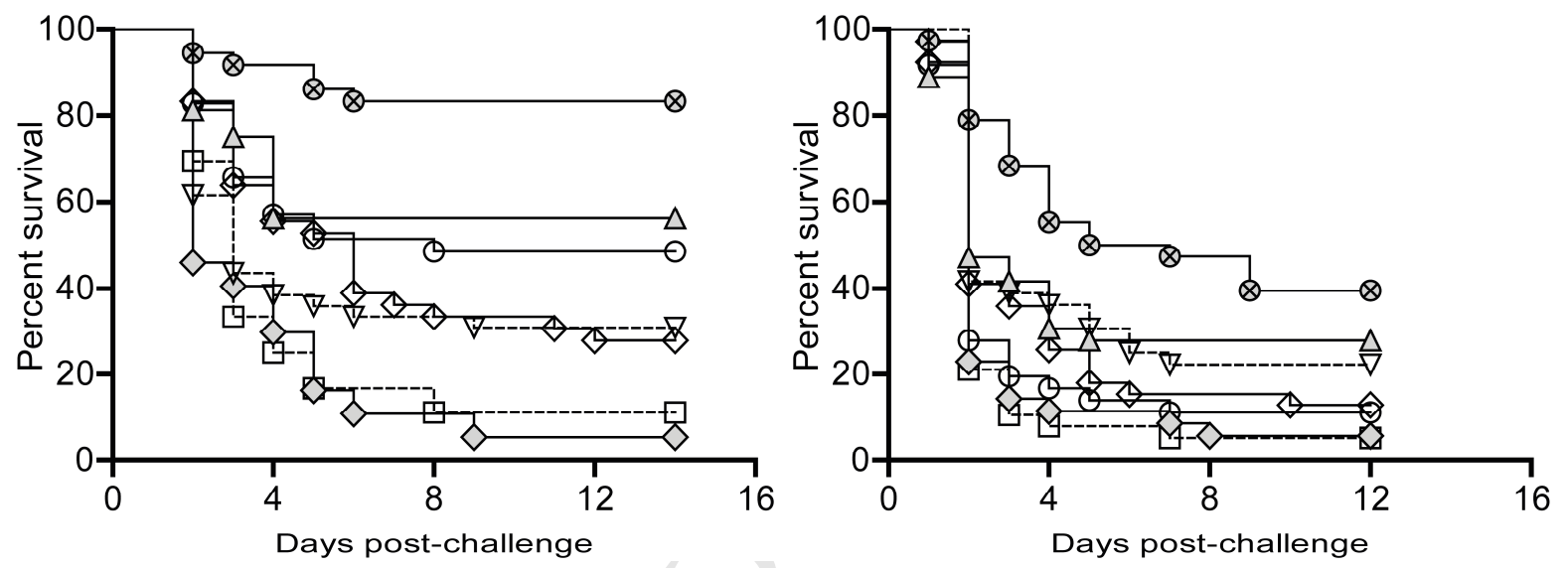


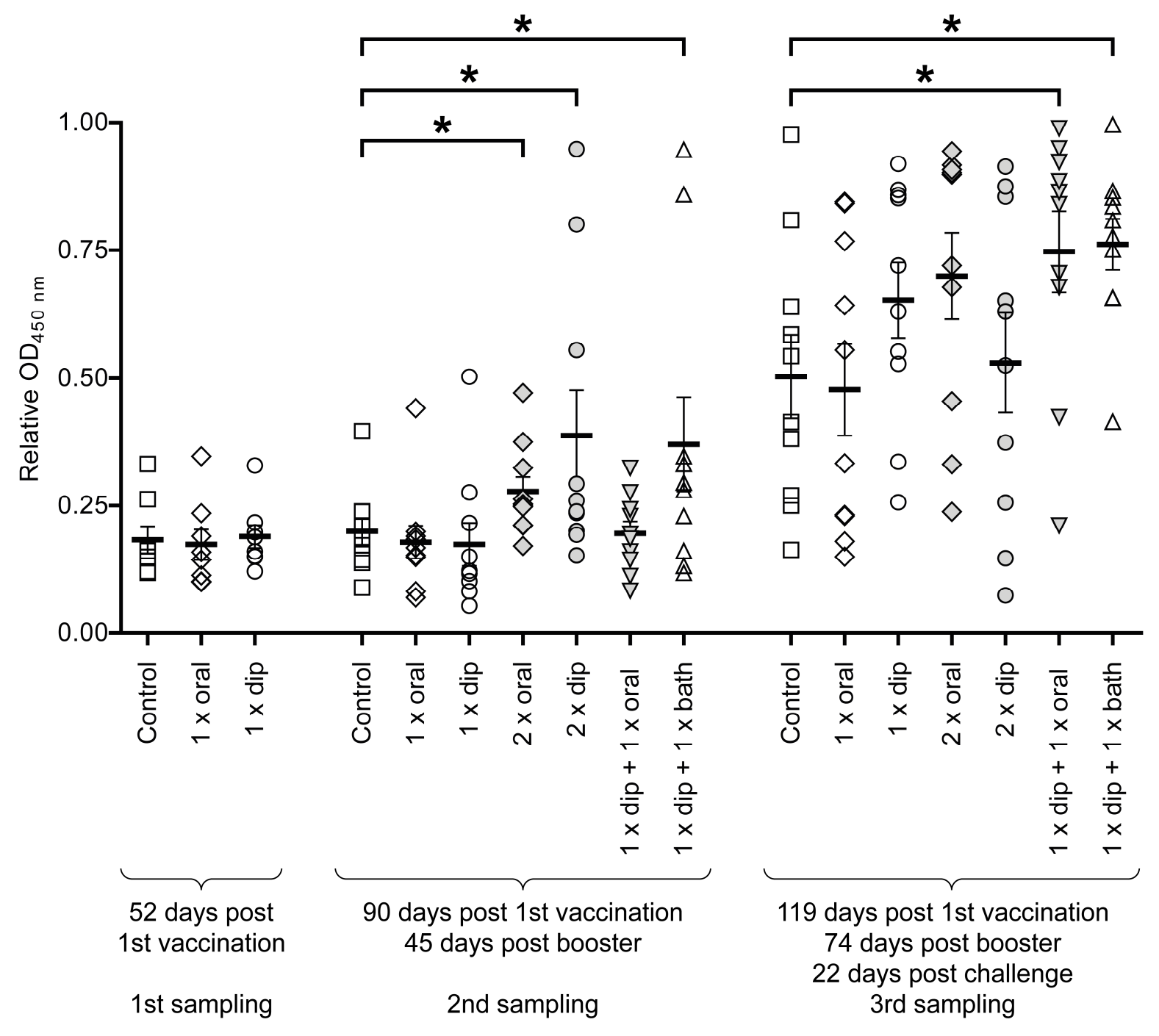




\section{Highlights for the manuscript}

- Vaccine induced protection of rainbow trout can be optimized by booster immunization either provided as dip (most effective), bath (less effective) or orally (least effective).

- Oral immunization may be used as booster after dip vaccination but applied as a single oral application it induced merely a slight immune response.

- Oral primary vaccination followed by an oral booster conferred no protection. 